\title{
Fabrication of 3D Printed Poly(lactic acid)/Polycaprolactone Scaffolds Using TGF- $\beta 1$ for Promoting Bone Regeneration
}

\author{
Cheng-Hsin Cheng ${ }^{1,2}$, Ming-You Shie ${ }^{3,4,5}$, Yi-Hui Lai ${ }^{6}$, Ning-Ping Foo ${ }^{1,7}$ (D), Mon-Juan Lee ${ }^{8,9, *(\mathbb{D})}$ \\ and Chun-Hsu Yao $6,10,11,12, *$ (D)
}

check for

updates

Citation: Cheng, C.-H.; Shie, M.-Y.; Lai, Y.-H.; Foo, N.-P.; Lee, M.-J.; Yao, C.-H. Fabrication of 3D Printed Poly(lactic acid)/Polycaprolactone Scaffolds Using TGF- $\beta 1$ for Promoting Bone Regeneration. Polymers 2021, 13, 3731. https:// doi.org/10.3390/polym13213731

Academic Editors: Jin-Jia Hu and Solaiman Tarafder

Received: 8 September 2021

Accepted: 22 October 2021

Published: 28 October 2021

Publisher's Note: MDPI stays neutral with regard to jurisdictional claims in published maps and institutional affiliations.

Copyright: (c) 2021 by the authors. Licensee MDPI, Basel, Switzerland This article is an open access article distributed under the terms and conditions of the Creative Commons Attribution (CC BY) license (https:// creativecommons.org/licenses/by/ $4.0 /)$
1 Graduate Institute of Medical Sciences, Chang Jung Christian University, Tainan 71101, Taiwan; u701018.tw@yahoo.com.tw (C.-H.C.); ningping.tw@gmail.com (N.-P.F.)

2 Department of Neurosurgery, An Nan Hospital, China Medical University, Tainan 70965, Taiwan

3 3D Printing Medical Research Center, China Medical University Hospital, Taichung 40402, Taiwan; gold018@gamil.com.tw

4 School of Dentistry, China Medical University, Taichung 40402, Taiwan

5 Department of Bioinformatics and Medical Engineering, Asia University, Taichung 40402, Taiwan

6 Department of Biomedical Imaging and Radiological Science, China Medical University, Taichung 40402, Taiwan; gold8701018@gmail.com

7 Department of Emergency Medicine, An Nan Hospital, China Medical University, Tainan 70965, Taiwan

8 Department of Bioscience Technology, Chang Jung Christian University, Guiren Dist., Tainan 711301, Taiwan

9 Department of Medical Sciences Industries, Chang Jung Christian University, Guiren Dist., Tainan 711301, Taiwan

10 School of Chinese Medicine, China Medical University, Taichung 40402, Taiwan

11 Biomaterials Translational Research Center, China Medical University Hospital, Taichung 40402, Taiwan

12 Department of Biomedical Informatics, Asia University, Taichung 40402, Taiwan

* Correspondence: mjlee@mail.cjcu.edu.tw (M.-J.L.); chyao@mail.cmu.edu.tw (C.-H.Y.); Tel.: +886-6-2785123 (M.-J.L.); +886-4-22081447 (C.-H.Y.)

Abstract: Our research was designed to evaluate the effect on bone regeneration with 3-dimensional (3D) printed polylactic acid (PLA) and 3D printed polycaprolactone (PCL) scaffolds, determine the more effective option for enhancing bone regeneration, and offer tentative evidence for further research and clinical application. Employing the 3D printing technique, the PLA and PCL scaffolds showed similar morphologies, as confirmed via scanning electron microscopy (SEM). Mechanical strength was significantly higher in the PLA group (63.4 MPa) than in the PCL group (29.1 MPa) $(p<0.01)$. Average porosity, swelling ratio, and degeneration rate in the PCL scaffold were higher than those in the PLA scaffold. SEM observation after cell coculture showed improved cell attachment and activity in the PCL scaffolds. A functional study revealed the best outcome in the 3D printed PCL-TGF- $\beta_{1}$ scaffold compared with the 3D printed PCL and the 3D printed PCL-Polydopamine (PDA) scaffold $(p<0.001)$. As confirmed via SEM, the 3D printed PCL- transforming growth factor beta 1 (TGF- $\left.\beta_{1}\right)$ scaffold also exhibited improved cell adhesion after $6 \mathrm{~h}$ of cell coculture. The 3D printed PCL scaffold showed better physical properties and biocompatibility than the 3D printed PLA scaffold. Based on the data of TGF- $\beta_{1}$, this study confirms that the 3D printed PCL scaffold may offer stronger osteogenesis.

Keywords: bone regeneration; polycaprolactone; poly-lactic acid; three-dimensional printing; transforming growth factor- $\beta$

\section{Introduction}

Currently, the demand for bone graft materials is increasing significantly [1]. Research on several forms of bone substitutes has been ongoing for years concerning the repair of defects [2-4]. Important factors that are considered for an ideal bone substitute material are the capability to transport cells, induce differentiation of osteoblasts, biocompatibility, osteoinductivity, osteoconductivity, proper biodegradation, and the development of osteoblasts in the defective space [5-7]. 
Additive manufacturing (AM) may be an option when traditional manufacturing has limitation of application. Rapid prototyping, functional integration, lightweight design, a design policy for high degree freedom have been developed. The technique of AM can be applied not only for production using other optimized methods in design but also prototyping including ideal support, ideal topology and options of partial consolidation and partial orientation [8]. AM procedures are also known as 3-dimensional (3D) printing, an improvement of techniques that decades ago permitted the construction of flat pieces from digital files [9]. The 3D printed structures are manufactured layer-by-layer with an injected cement or biomaterials [10,11]. The benefits of 3D printed frameworks are designable porosity, structure pore shape, and morphology, as compared with conventional procedures [12]. 3D biomedical devices are critical in tissue engineering because of the ability to design and fabricate complexes. Custom-made transplants can be made with precisely designed constructions according to the 3D image data of patients, which offers great superiority over traditional procedures for manufacturing 3D porous scaffolds, such as salt-leaching/ solvent-casting, air jet spinning, gas foaming, and electrospinning techniques [13-16]. Current 3D printing procedures offer opportunities for better conventional bone substitutes, providing sufficient pore interconnection, pore shape, and optimal porosity [17].

Polylactic acid (PLA) is one of the substances in our 3D printed scaffold. PLA is a bio-based material presenting fascinating physical, chemical and mechanical properties such as sufficient biodegradability, simple processing, and high ductility and hardness [18]. However, it displays some limitations such as poor water solubility, and being frangible [19]. Owing to its good accessibility, PLA is currently one of the most broadly applicable biodegradable polymers for various uses in packaging, electronic industries, automotive industries, and prosthesis fabrication, substituting effectively for petroleum-based polymers [20,21]. Many trends in orthopedic practice and research have suggested that PLA is safe and nontoxic [22]. Numerous studies have demonstrated the biocompatibility of these biomaterials in vivo and in vitro [23]. In a study, appropriate tissue biocompatibility was reported when PLA was used as a graft in the femoral shaft of sheep [24]. PLA and its substitutes have also been commonly applied in bone repair and have shown to have sufficient biological adaptation, be nontoxic, and noninflammatory [25]. Transplants made of PLA were shown to enhance bone repair in rats and create better bone regeneration than controls in skull defects [26].

Polycaprolactone (PCL) is another material in our 3D printed scaffold. As a biomaterial for scaffold construction, PCL offers several advantages, such as adjustable biodegradation and relatively high mechanical properties at physiological temperatures [27]. The biocompatibility and degradation of PCL can be modified by merging it with other biomaterials to develop composite biomaterials for bone repair [28]. With the combination of copolymerization, or mixing with other substances, PCL properties can be improved. PCL has sufficient hardness and mechanical stiffness under physiological conditions owing to its poor glass transition temperature and semicrystalline ability [25,29]. For efficient tissue engineering, the surface of the PLA framework is often modified with hydrophilic substances to enhance cell binding and growth. However, owing to its slow degeneration, PCL is combined with other polymers and ceramic substances to modify its degradation for a specific application [30].

MG-63 cell is one of the osteosarcoma cell lines. All investigated osteosarcoma cell lines (e.g., MG-63, Saos-2 and U-2 OS) exhibit very heterogeneous labelling profiles and each differs from typical osteoblasts. The osteosarcoma cell line displays a characteristic labelling profile that offers a differently composed extracellular matrix. This can be used to better characterize osteosarcoma, as well as for its diagnosis [31]. In one MG-63 cell study, proliferation was more rapid than in other osteoblast-like cells with a short doubling time. MG-63 cells also had increased enzyme activity following 1,25-dihydroxyvitamin D3 $(1,25(\mathrm{OH}) 2 \mathrm{D} 3)$ administration, which is characteristic of bone-derived cells [32]. This cell line was used for the study of bone cell culture and was effective in bone growth. 
In the production of scaffolds with appropriate physical properties, 3D printing is the most adopted methodology [33]. Although 3D printed scaffolds have exhibited acceptable bone tissue repair, the performance of synthetic substances is usually affected by many biological factors [34]. The advantage of 3D printing lies in facilitating the design of a variety of different configurations of the skeleton. To enhance bone regeneration with 3D printed scaffolds, we used dopamine (DA)-mediated immobilization for transforming growth factor beta 1 (TGF- $\beta_{1}$ )-derived peptides onto biodegradable 3D printed scaffolds to promote bone regeneration. DA has a catechol functional structure that can increase polymerisation through oxidative transformation from catechol to quinone $[35,36]$. Polydopamine (PDA) can cover the surface of the scaffold as a thin layer [36,37]. Many researchers have shown that thiolated polysaccharides, peptides, enzymes, growth factor proteins, and anticancer drugs (e.g., neurotrophic and angiogenic abilities) can be efficiently grafted onto DA-coated material structures $[38,39]$. The role of TGF- $\beta_{1}$ is crucial for bone formation during the stages of cell proliferation, differentiation, and promotion of osteogenesis [40,41]. In this study, osteoinductive peptides derived from TGF- $\beta_{1}$ could be effectively fixed onto 3D printed scaffolds through the PD-mediated coating technique [42].

The objectives of our study are to explore the biological and physical properties of 3D printed PLA and PCL. As we know, 3D printing is advantageous because it provides an appropriate structure. However, different materials may have different effects on bone repair. Our aim is to improve bone regeneration and develop 3D printed scaffolds with better artificial biomaterials for artificial bone.

\section{Material and Methods}

\subsection{Creation of $3 D$ Printed PLA and PCL Scaffolds}

Each 3D printed scaffold was devised with the SpaceClaim 2014 CAD package (SpaceClaim Corporation, Concord, MA, USA). In the 3D printing machine, a cartridge was applied to supply the feedstock filament of polymers (Pitotech, Changhua City, Taiwan) into the fused deposition modeling (FDM) 3D printer (Prusa I3). The PLA or PCL strand was drawn, merged and extruded over the printing head to layer beads. The printer had the ability to mix up to three separate threads with a diameter of $0.2 \mathrm{~mm}$. The thickness of each layer for the designed scaffolds was set to $0.2 \mathrm{~mm}$ in order to achieve better support and permeability with good printing quality. The scaffold was set with a cylindrical outline with a height of $8 \mathrm{~mm}$ and a diameter of $6 \mathrm{~mm}$.

\subsection{Analysis of Physical Property}

\subsubsection{Mechanical Testing}

Mechanical compression was measured with a SHIMADZU (AG-10KNIS) testing device using a $10 \mathrm{kN}$ load cell according to the guiding procedure set in ASTMD502495a [43]. Each group of data was tested for five samples $(n=5)$.

\subsubsection{Measurement of Porosity}

The specific gravity method was used to test porosity. At a temperature of $37^{\circ} \mathrm{C}$, the scaffold $\left(\mathrm{m}_{\mathrm{s}}\right)$ was immersed in ethanol $\left(\mathrm{m}_{0}\right)$, making sure all pores in each sample were filled with ethanol $\left(\mathrm{m}_{1}\right)$, then the soaked specimen was removed. The remaining weight of the ethanol and specific gravity bottle was recorded as $\mathrm{m}_{2}$. Porosity was calculated as Porosity $=\left(\mathrm{m}_{1}-\mathrm{m}_{2}-\mathrm{m}_{\mathrm{s}}\right) /\left(\mathrm{m}_{0}-\mathrm{m}_{2}\right)$.

\subsubsection{Measurement of Swelling Ratio}

The samples were fully immersed in Sorensen's buffer fluid. After immersion for different time points at $37^{\circ} \mathrm{C}$, the samples were taken out, air-dried with filter paper, and weighed $\left(W_{t}\right)$. Next, these scaffolds were frozen, dehydrated, and weighed (record as $W_{0}$ ). The swelling percentage $(\Delta W \%)$ was calculated as $\Delta W(\%)=\left(W_{t}-W_{0}\right) / W_{0} \times 100(\%)$ [44]. 


\subsubsection{Degradation Rate Measurements}

The rate of degradation was estimated under ISO 10993 guidelines. All the studied scaffolds were weighed (record as $\mathrm{W}_{0}$ ) and put into testing tubes with $3 \mathrm{~mL}$ of Sorensen buffer. Each sample tube was left at $37^{\circ} \mathrm{C}$. At scheduled time points after soaking, all sample scaffolds were removed from the Sorensen buffer, freeze-dried, and weighed (recorded as $W_{\mathrm{t}}$ ). The weight loss percentage (recorded as $\Delta W \%$ ) was then calculated $\left(\Delta W \%=\left(W_{0}-W_{t}\right) / W_{0} \times 100 \%\right)$. Each rate of degradation was defined by dividing its $\Delta W \%$ by the different soaking time point.

\subsection{Analysis of Biocompatibility In Vitro}

Stem Cells Culture by Scanning Electron Microscopy (SEM) Observation

MG-63 cells (BCRC, number 60279) were cocultured with scaffolds as a single layer in low-glucose Dulbecco modified Eagle medium (DMEM) (D6046, Sigma, Taipei, Taiwan) with $1 \% \mathrm{PS}$ and $10 \% \mathrm{FBS}$ under $37^{\circ} \mathrm{C}, 5 \% \mathrm{CO}_{2}$, and $95 \%$ air in a humidified setting. After the setup time point, seeded scaffolds were irrigated several times by $1 \times$ phosphate buffered saline (PBS), immobilized in $2 \%$ glutaraldehyde for $48 \mathrm{~h}$, and critical point dehydrated. Then, the samples were sputter-covered with platinum for $200 \mathrm{~s}$ by vacuum and observed by SEM (S-3000; Hitachi, Tokyo, Japan) at $15 \mathrm{kV}$.

\subsection{Coating Poly(dopamine) and Immobilized TGF- $\beta_{1}$}

Coating of PDA (H8502, Sigma, Taipei, Taiwan) on the surface of PCL scaffold sample was performed using an immersion coating procedure. The PCL scaffold was placed in $0.5 \mathrm{~mL}$ DA fluid (pH 8.5, $2 \mathrm{mg} / \mathrm{mL}$ in $10 \mathrm{mM}$ Tris, H8502, Sigma, Taipei, Taiwan) with a shaker at 25 -rpm at $37^{\circ} \mathrm{C}$ for $12 \mathrm{~h}$, followed by several washes with deionized water according to our previous study [45]. The PDA-coated PCL scaffold samples were placed in the TGF- $\beta_{1}$ fluid ( $\mathrm{pH} 8.5,10$ or $20 \mathrm{ng} / \mathrm{mL}, 10 \mathrm{mM}$ Tris-HCl buffer PeproTech, London, $\mathrm{UK}$ ) and left at a temperature of $37^{\circ} \mathrm{C}$ overnight.

\subsubsection{Quantification of Immobilized TGF- $\beta_{1}$}

We used an enzyme-linked immunosorbent assay (ELISA assay) (Cat.88-8350-88, Invitrogen) for measurement of TGF- $\beta_{1}$ concentration on the scaffolds. For the preparation of different concentrations of TGF- $\beta_{1}$ solution for the calibration curve, we conducted the TGF- $\beta_{1}$ capture antibody reaction at $4{ }^{\circ} \mathrm{C}$ overnight. Aspirated wells were then washed three times by wash buffer solution and block by $200 \mu \mathrm{L}$ ELISA Diluent (1X) at room temperature for $1 \mathrm{~h}$. Aspirated wells were washed several times with wash buffer solution and $100 \mu \mathrm{L} /$ well residual solution added for a reaction period of $2 \mathrm{~h}$. Aspirated wells were irrigated three times by wash buffer, and rhBMP-2 added for $1 \mathrm{~h}$ for antibody. Aspirated wells were then washed three times with wash buffer, and avidin-HRP added for $30 \mathrm{~min}$. The aspirated wells were then washed three to four times with wash buffer and reacted with $100 \mu \mathrm{L}$ TMB for $15 \mathrm{~min}$. The procedure was finished with $2 \mathrm{~N} \mathrm{HCl}$. An ELISA reader was used to read absorbance $(450 \mathrm{~nm})$. The interpolation method in the ELISA calibration curve was made to calculate the residual content of the TGF- $\beta_{1}$ solution. This was calculated as immobilized concentration of TGF- $\beta_{1}$ equals TGF- $\beta_{1}$ concentration before reaction minus TGF- $\beta_{1}$ concentration after reaction.

\subsubsection{TGF- $\beta_{1}$ Release Test}

We used an enzyme-linked immunosorbent assay (ELISA) to check the long-term release kinetics of TGF- $\beta_{1}$ indirectly. For this step, supernatants were entirely assembled and cleaned by PBS solution on days 1, 3, 5, 7, 14, 21, and 28. The supernatants (1 mL) at different time point were preserved at $-70{ }^{\circ} \mathrm{C}$ until the ELISA study.

\subsubsection{ALP Assay}

MG-63 cells were placed onto 24 well cell culture plates at $1 \times 10^{4}$ cells/well and $300 \mu \mathrm{L}$ of sample scaffold soaking solution was added after 7 days. Thereafter, the medium 
was extracted and the stem cells were irrigated by PBS solution. A volume of $200 \mu \mathrm{L} /$ well of ALP reagent (SIGMAFAST ${ }^{\mathrm{TM}}$ pNPP substrate, Simga N2770) was placed in the dark for $30 \mathrm{~min}$, and $405 \mathrm{~nm}$ wavelength absorption read using an ELISA detector.

\subsubsection{Cytotoxicity Testing}

The (3-(4,5-dimethylthiazol-2-yl)-2,5-diphenyl tetrazolium bromide; Cat.298-93-1, USB) (MTT) assay was performed on the reduction of MTT using the mitochondrial enzyme (succinate dehydrogenase) to develop insoluble dark-blue formazan.

Co-cultured cells constituted an osteoblast-like cell strand (MG-63 cell) from the Food Industry Research and Development Institute (FIRDI, Hsinchu, Taiwan). Osteoblasts cocultured with 3D printed scaffolds were used to check biocompatibility in vitro. The MG-63 cells were placed into 24 well cell culture dishes at $1 \times 10^{4}$ cells / well, and $300 \mu \mathrm{L}$ of 3D printed scaffold soaking solution incubator was added for 7 days. In this study, the scaffolds were immersed in $180 \mu \mathrm{L}$ /well of culture solution and $20 \mu \mathrm{L} /$ well of MTT medium, at a temperature of $37^{\circ} \mathrm{C}$ for $4 \mathrm{~h}$ to develop crystals of formazan. The fluid was then extracted and $200 \mu \mathrm{L} /$ well of acid propan-2-ol was dripped into all the wells and gently stirred to melt the dark-blue crystals. After a few minutes at $37^{\circ} \mathrm{C}$, the plates were detected by an ELISA machine (570 nm wavelength compared with a reference $650 \mathrm{~nm}$ wavelength). The accumulation of vital cells was recorded by converting the optical density (O.D) values according to the MTT study.

\section{Results}

\subsection{Demonstration of PLA and PCL Scaffolds}

We developed 3D printed PLA and PCL scaffolds with similar shapes (Figure 1). Measured by SEM, the line width and pore size were almost the same in the 3D printed PLA and PCL scaffolds (Table 1). This showed that, even with different materials, the morphology was the same employing the 3D printed technique. For a better cell environment, an optimal scaffold microarchitecture should have maximum porosity with interconnected channels of ideal widths (approximately 200 to $900 \mu \mathrm{m}$ in diameter) [46] and have a maximal surface area to permit sufficient rates of substance transfer, neo-vascularization and cell in-growth, [47]. The average pore sizes of our designed 3D printed scaffold were $684 \mu \mathrm{m}$ or $682 \mu \mathrm{m}$. This is suitable for cell growth.

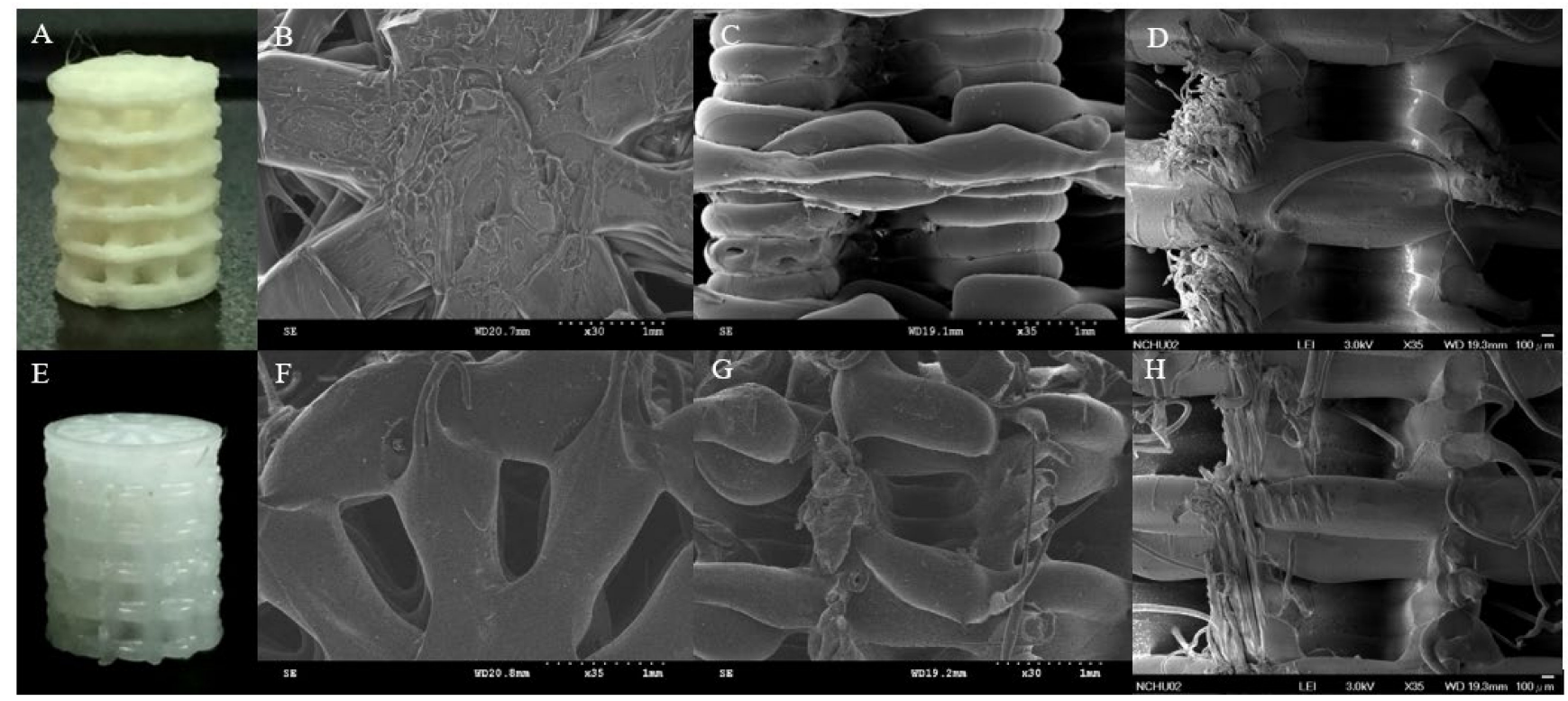

Figure 1. Morphology of 3D printed PLA and 3D printed PCL scaffold. The appearance of PLA (A) and PCL (E) scaffold. The top view, side view, and cross section of PLA (B-D) and PCL (F-H) scaffold under SEM study. 
Table 1. Pore size and line width of 3D printed PLA and PCL scaffold $(n=5)$.

\begin{tabular}{ccc}
\hline & Pore Size $(\mu \mathrm{m})$ & Line Width $(\mu \mathrm{m})$ \\
\hline 3D printed PLA & $684 \pm 66$ & $246 \pm 34$ \\
3D printed PCL & $682 \pm 50$ & $277 \pm 36$ \\
\hline
\end{tabular}

The mechanical strength was significantly better in the 3D printed PLA scaffold than 3D printed PCL scaffold (Figure 2). With the same architecture of these two experimental scaffolds, the mechanical strength was influenced by the different material characteristics. The Young's modulus of human cortical bone is from 1 to 20 GPa with a strength from 1 to $100 \mathrm{MPa}$ [48]. The corresponding data for cancellous bone is 0.1 to $1.0 \mathrm{GPa}$ and 1 to $10 \mathrm{MPa}$, respectively [49]. Although a wide range is reported for the mechanical strength of human natural bone, the values are references for determining the required mechanical properties of an ideal scaffold [50]. Our data show that both PLA and PCL scaffolds offer sufficient supportive strength.

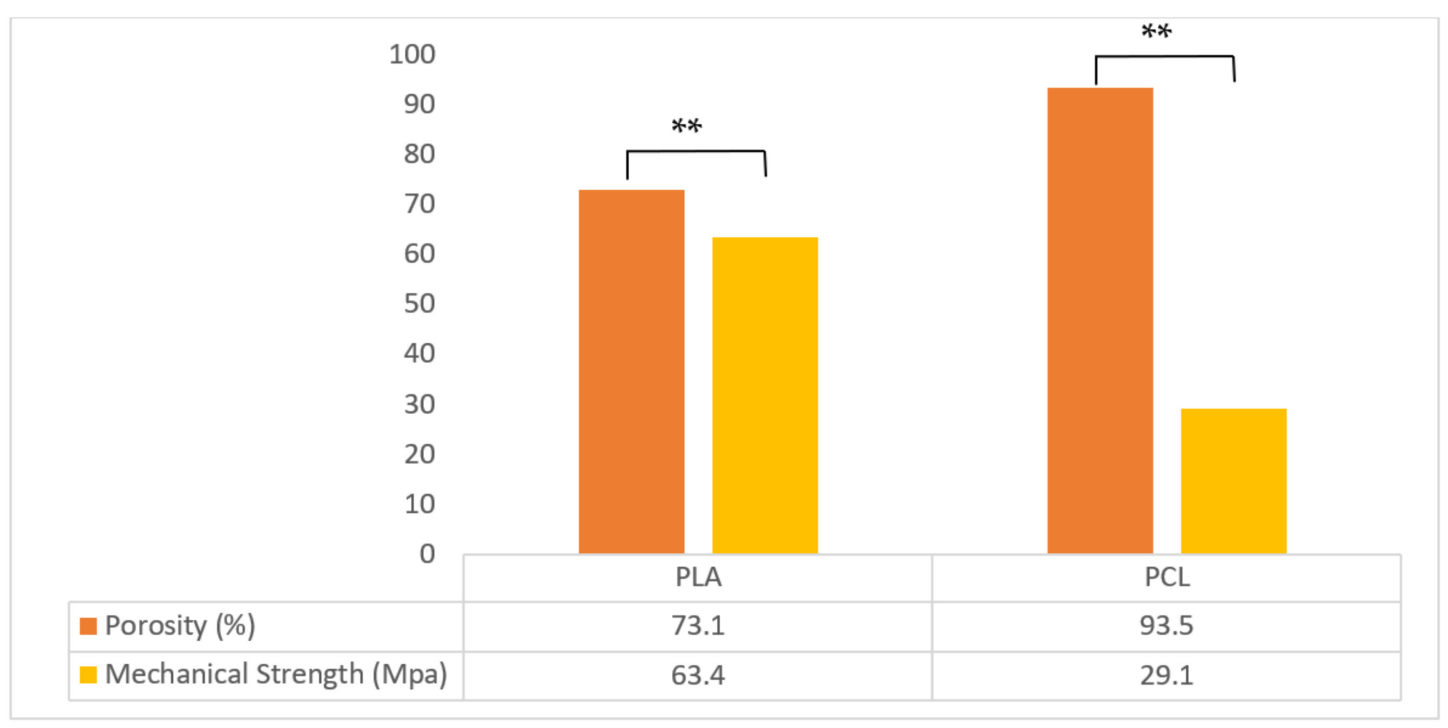

Figure 2. Porosity and mechanical strength of the 3D printed PLA and PCL scaffolds. Significantly different porosity and mechanical strengths are shown $(* * p<0.01, n=5)$.

Porosity is related to the number of cell implants, connectivity of the pores, and strength of the structure [28]. The larger the porosity, more cells can be implanted. A larger porosity can offer better adherence and growth space. However, a larger porosity may cause weaker mechanical strength [51]. The porosity was 93.5\% in the PCL scaffold and $73.1 \%$ in the PLA scaffold $(p<0.01)$ (Figure 3$)$. In the study of swelling ratio, stability was attained after $24 \mathrm{~h}$ of immersion (Figure 4). The swelling ratio of PLA was lower than that of the PCL scaffold. According to the porosity, surface contact was greater in the PCL. Better surface contact may result in more water absorption and an advanced swelling ratio. Similar data were observed in the degradation test (Figure 4). The degradation rate was higher in the PCL scaffold than in the PLA group. These results may be the consequence of poor PLA biodegradability [52]. 


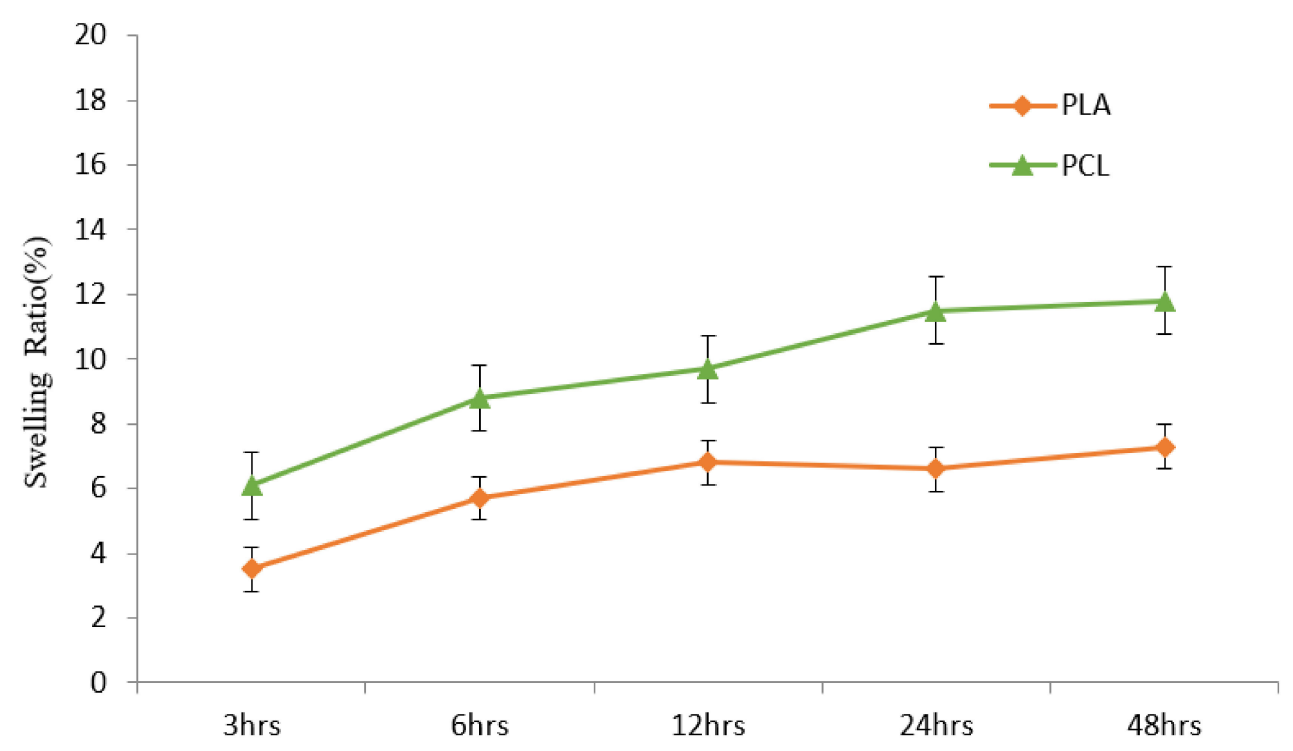

Figure 3. Swelling ratio of the 3D printed PLA and PCL scaffolds for $48 \mathrm{~h}$ of immersion. The swelling rate is higher in the PCL group after $48 \mathrm{~h}(n=5)$.

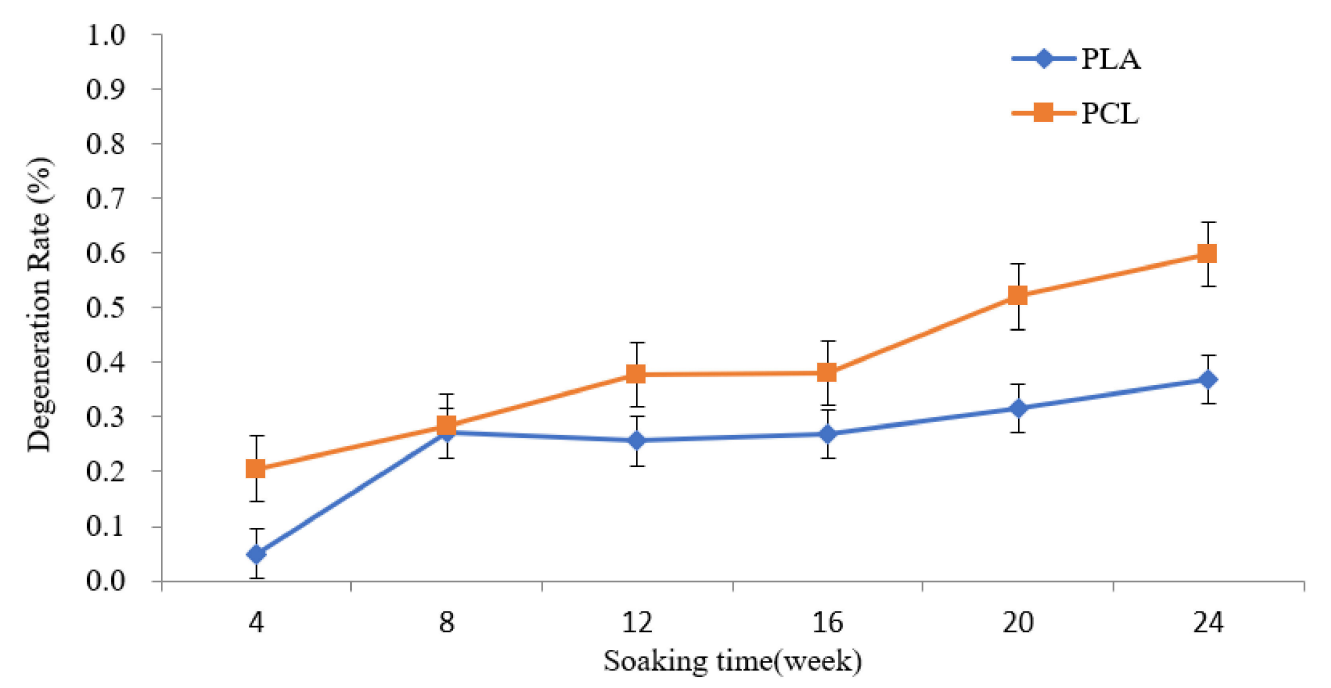

Figure 4. Degeneration rate of 3D printed PLA and PCL scaffolds for $24 \mathrm{~h}$ of immersion. The degeneration rate is higher in the PLA group $(n=5)$.

\subsection{Biocompatibility}

A cell culture study was prepared to estimate biocompatibility. MG-63 cells were cocultured with scaffolds for $24 \mathrm{~h}$. The cells were observed by SEM (Figure 5). MG-63 cells were attached well to both 3D printed PLA and PCL scaffolds, producing pseudopodia, and showed increased cell adhesion and growth in the PCL scaffold. This implies that the 3D printed PCL scaffold is more favorable for cell growth than the PLA scaffold in vitro. However, the PLA may release lactate during degradation. A low $\mathrm{pH}$ may cause cell damage and poor cell attachment [53]. The 3D printed PCL in this study exhibited excellent biocompatibility. 


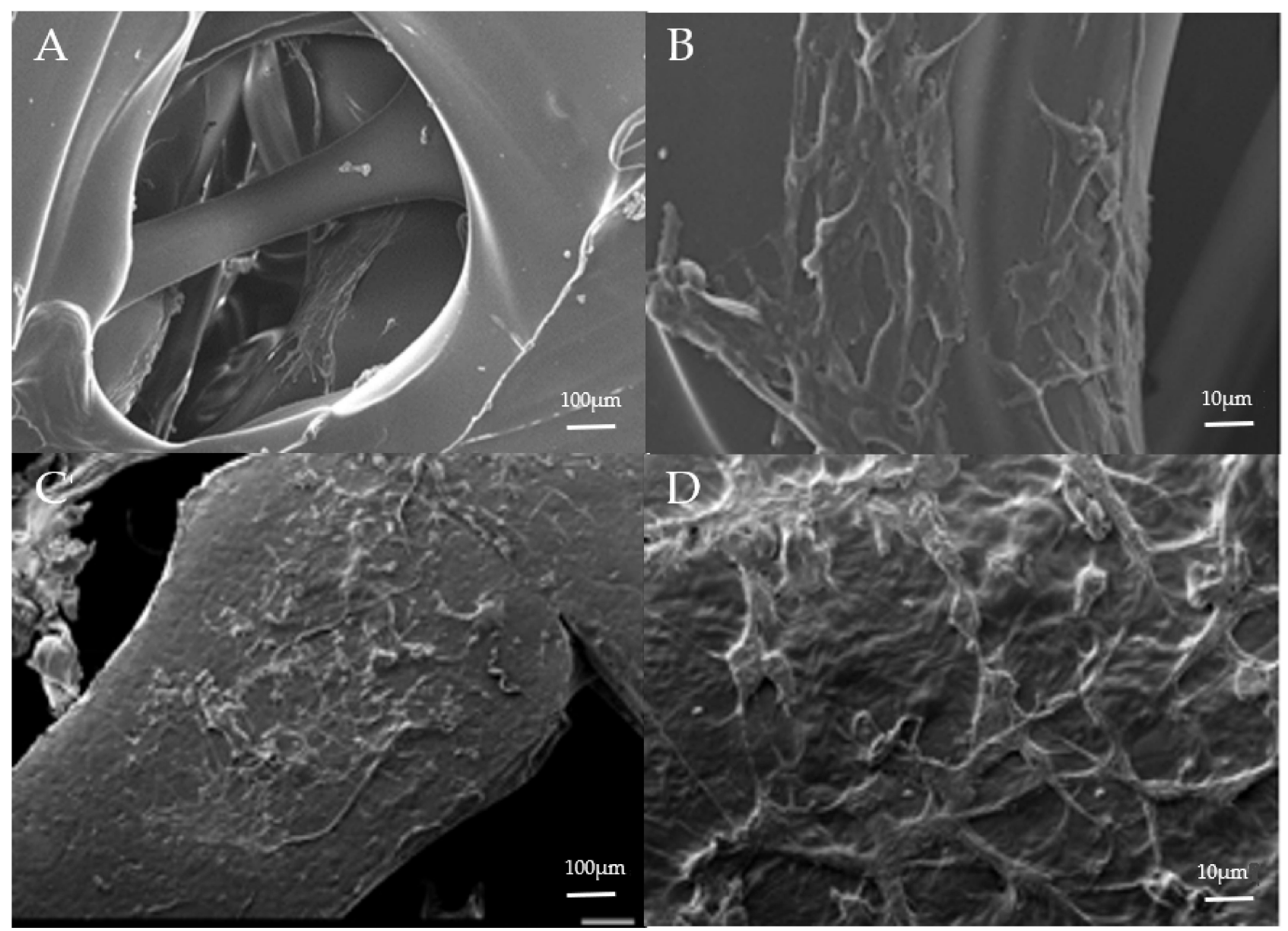

Figure 5. Cell culture in the 3D printed PLA (A,B) and PCL (C,D) scaffolds. Good cell adaption and adhesion were seen in both scaffolds. In gross view, more cell growth is seen in the PCL scaffold.

\subsection{Coating PDA and Immobilized TGF- $\beta_{1}$}

\subsubsection{Quantification of Immobilized TGF- $\beta_{1}$}

To identify the best concentration of TGF- $\beta_{1}$ for PDA grafting, the PD-coated scaffold was immersed in two concentrations of TGF- $\beta_{1}$ (Figure 6). The $10 \mathrm{ng} / \mathrm{mL}$ concentration of TGF- $\beta_{1}$ is represented as TGF- 10 . The $20 \mathrm{ng} / \mathrm{mL}$ concentration of TGF- $\beta_{1}$ is represented as TGF-20. The average levels of grafted TGF- $\beta_{1}$ on the PDA-coated scaffold in TGF-10 and TGF-20 were 9.69 and $19.30 \mathrm{ng} / \mathrm{scaffold}$. This implies that TGF- $\beta_{1}$ could be fixed on the surface of the material through PDA connection. The concentration of immersed TGF- $\beta_{1}$ was proportional to the level of fixed TGF- $\beta_{1}$ on the scaffold. The fixation rates of the two groups reached above $50 \%$. As mentioned above, we believe that, through PD grafting, TGF- $\beta_{1}$ can be successfully fixed on the scaffold and has an appropriate fixed efficiency.

\subsubsection{TGF- $\beta_{1}$ Releasing Test}

We designed the study to analyze TGF- $\beta_{1}$ releasing level with different concentrations of TGF- $\beta_{1}$ grafting $(10 \mathrm{ng} / \mathrm{mL}, 20 \mathrm{ng} / \mathrm{mL}$ ) for 35 days in vitro (Figure 7). There was no abrupt release in the two groups within 7 days. The final accumulated TGF- $\beta_{1}$ releasing levels in TGF-10 and TGF-20 for 35 days were $541.87 \mathrm{pg} / \mathrm{mL}$ and $621.355 \mathrm{pg} / \mathrm{mL}$. The TGF-20 scaffold released more TGF- $\beta_{1}(p>0.001)$, implying that TGF- $\beta_{1}$ could be slowly released from the scaffold over time. To confirm the effective concentration of TGF- $\beta_{1}$ for bone growth, the ALP assay was evaluated by coculture with MG-63 cells with different levels of TGF- $\beta_{1}$ (Figure 8). A quantity of $100 \mathrm{pg} / \mathrm{mL}$ TGF- $\beta_{1}$ was most effective for ALP activity. Therefore, we compared TGF- $\beta_{1}$ releasing levels at different time periods in the 
two groups. The effective concentration of TGF- $\beta_{1}(100 \mathrm{pg} / \mathrm{mL})$ was almost achieved in the TNF- 20 group within 28 days. Considering cost and effectiveness, the best immersion concentration of TGF- $\beta_{1}$ for the PDA-coated scaffold may be $20 \mathrm{ng} / \mathrm{mL}$.

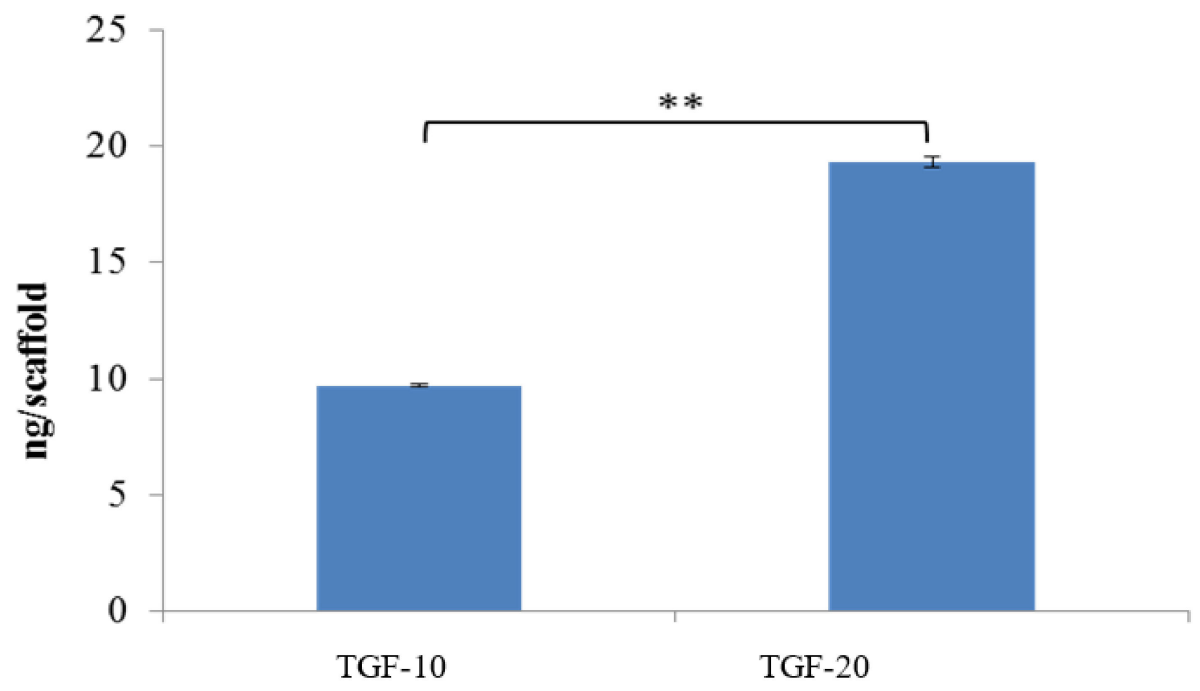

Figure 6. Concentration of TGF- $\beta_{1}$ on the PCL-coated scaffold in two groups, proving the TGF-20 can offer more TGF- $\beta_{1}$ concentration, $(* * p<0.01, n=5)$.

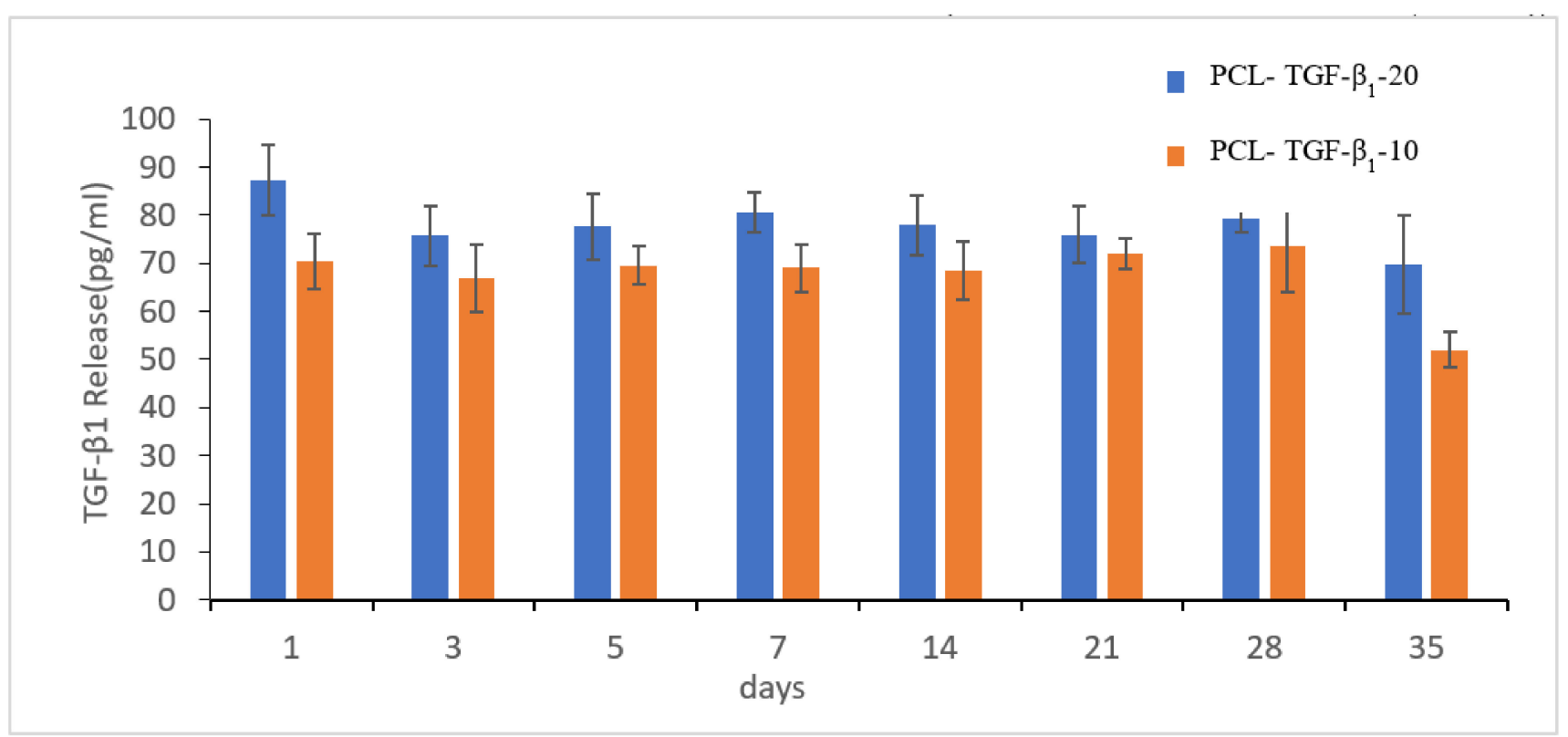

Figure 7. Analysis of TGF- $\beta_{1}$ releasing level in the PCL-coated TGF- $\beta_{1}-10$ (TGF- $\beta_{1}$ concentration: $10 \mathrm{ng} / \mathrm{mL}$ ) and PCLcoated TGF- $\beta_{1}-20$ (TGF- $\beta_{1}$ concentration: $20 \mathrm{ng} / \mathrm{mL}$ ) samples at different time points $(1,3,5,7,14,21,28,35$ days). The scaffold was able to release the TGF- $\beta_{1}$ persistently and regularly for one more month. Moreover, the PCL-coated TGF- $\beta_{1}-20$ produces a greater TGF- $\beta_{1}$ level $(n=5)$. 


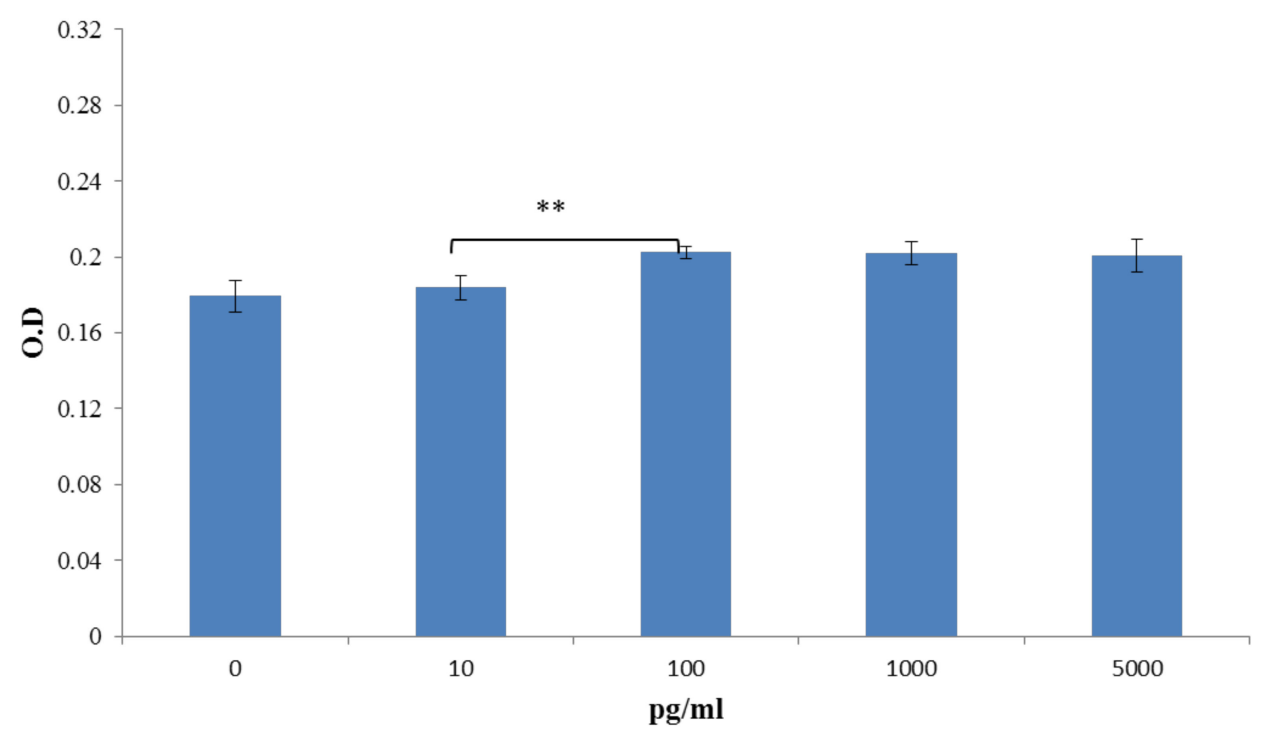

Figure 8. Optical density (O.D) of ALP assay by coculture with TGF- $\beta_{1}$ and MG-63 cells for 5 days. A concentration of $100 \mathrm{pg} / \mathrm{mL}$ TGF- $\beta_{1}$ has more influence on the ALP elevation, $\left({ }^{* *} p<0.01, n=5\right)$.

\subsubsection{MG-63 Culture by SEM Observation}

MG-63 cells were implanted onto the 3D printed PCL-TGF- $\beta_{1}$ scaffold for $6 \mathrm{~h}$. Cell adhesion and growth were observed by SEM. The stem cells were polygonal and roundshaped on the scaffold after $6 \mathrm{~h}$ of culture (Figure 9). Therefore, the 3D PCL scaffold with PDA-coated and TGF- $\beta_{1}$ grafting may be capable of enhancing cell transformation and growth.
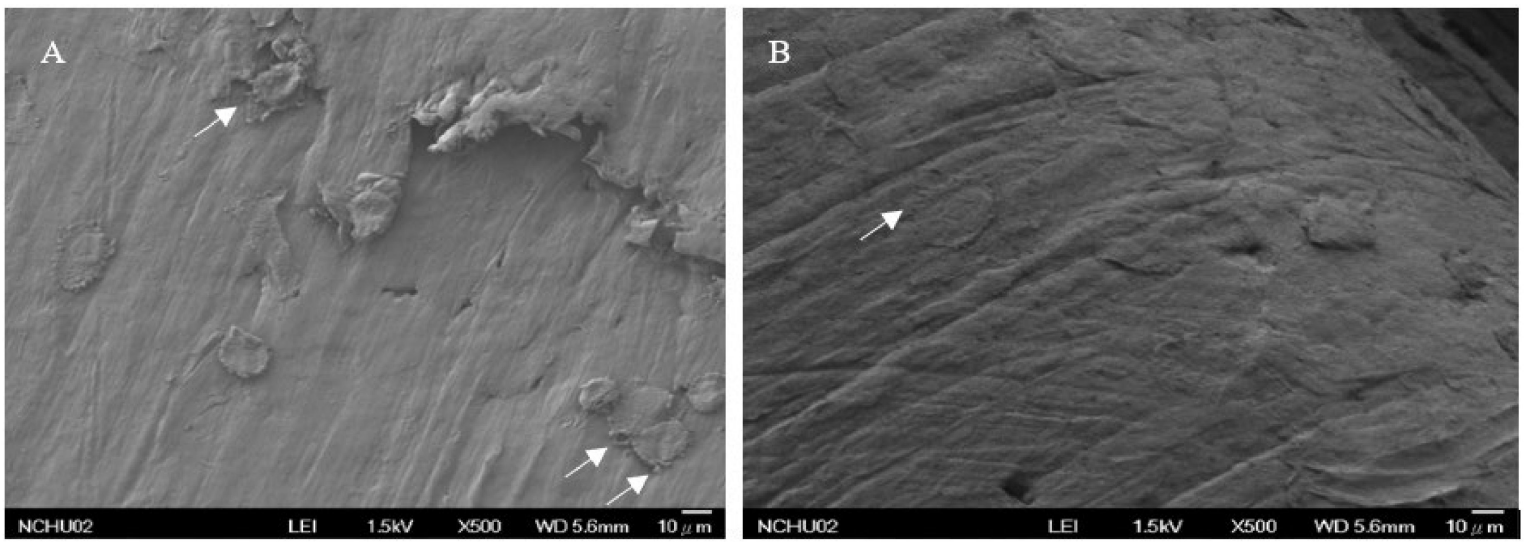

Figure 9. SEM observation of co-culture with MG-63 cells and the PCL-TGF- $\beta_{1}$ scaffold for $6 \mathrm{~h}(\mathbf{A}, \mathbf{B})$ showing good cell adhesion and typical cellular pseudopodia (white arrows).

\subsubsection{MTT Assay with MG-63 Culture}

An MTT assay was used to estimate degraded products on osteoblasts (Figure 10A). The cell count in the PCL-PDA and PCL-TGF- $\beta_{1}$ groups was higher than the PCL group. This revealed that the degraded products of PDA and TGF- $\beta$ may cause no toxicity and enhance cell activity. In addition, cell proliferation in the PCL and PCL-PDA scaffolds was better than that in the PCL-coated TGF- $\beta_{1}$ group $(p<0.01)$. We believe that the $3 \mathrm{D}$ printed PCL-TGF- $\beta_{1}$ scaffold has better biocompatibility because of PDA and TGF- $\beta_{1}$ grafting during manufacturing [54]. 


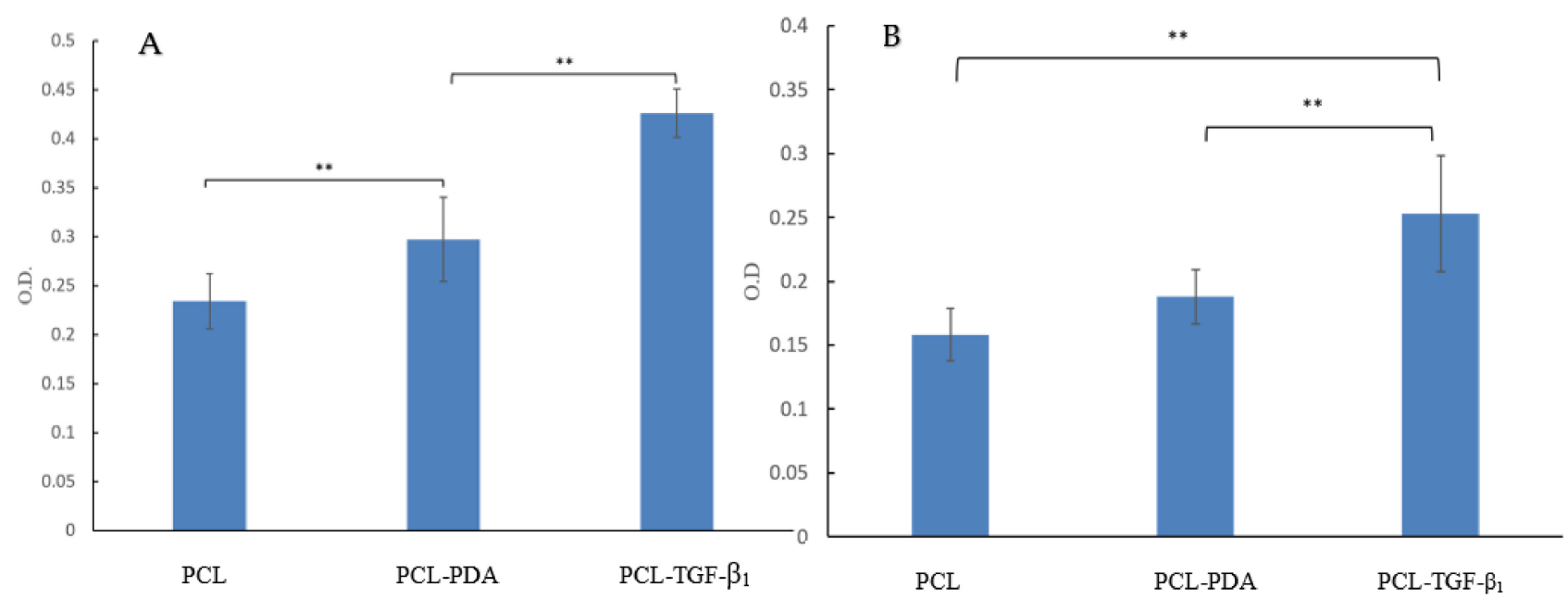

Figure 10. MTT assay after stem cell culture for 7 days (A). ALP assay after stem cell culture for 7 days (B). The PCL-TGF- $\beta_{1}$ group had significantly lower toxicity and higher ALP level $\left.{ }^{* *} p<0.01, n=6\right)$.

\subsubsection{ALP Assay with MG-63 Culture}

ALP is a protein commonly indicated for osteoblast differentiation [55]. We evaluated the ALP level on the cultured scaffold on the 7th day (Figure 10B). The ALP level was higher in the PDA-coated 3D printed PCL and PDA-coated TGF- $\beta_{1} 3$ D printed PCL scaffold than in the pristine 3D printed PCL scaffold. This may show the ability of cell transformation and growth after PDA coating and TGF- $\beta_{1}$ grafting. The highest ALP level was observed in the PCL-coated TGF- $\beta_{1}$ group $(p<0.01)$. This may prove that the PDA-coated TGF- $\beta_{1}$ $3 \mathrm{D}$ printed PCL scaffold has a better ability to enhance stem cell transfer to osteoblasts.

\section{Discussion}

The purpose of this research was to enhance the biological functionality of 3D printed synthetic scaffolds through coating with PDA and TGF- $\beta_{1}$. Many studies have demonstrated the significance of PDA and TGF- $\beta_{1}$ in bone regeneration $[35,42,56,57]$. However, the role and mechanism of $3 \mathrm{D}$ printed bone repair are not clearly understood [58]. We also attempted to evaluate the mechanism of bone repair in 3D printed scaffolds. Their capacity to induce the differentiation of newly seeded osteoblasts was also evaluated.

The 3D printing technique has lately been developed as a viable method for the construction of materials [59]. In particular, the melt extrusion printing method has allowed the deposition of polyesters frequently applied in biological engineering, such as PLA and PCL [60]. These polymers, and other generally extruded synthetic materials, are highly bioinert, demanding more deposition of bioactive substances [61]. The 3D printing method combined with biodegradable materials has been applied to create complicated structure for the repair of various organs or tissues, such as neural tissue, heart, cartilage and bone [62-64]. Therefore, 3D printing technology is superior to traditional methods.

Two different materials with the same 3D printed structure (PLA and PCL) were developed to evaluate their physical properties. In the 3D printed PCL scaffold, based on physical evaluation, we found that the pore size was approximately $682 \mu \mathrm{m}$, the porosity was up to $93.5 \%$, and the mechanical strength was less than that of the 3D printed PLA scaffold. Several studies have shown that high porosity with proper diameters from 300 to $900 \mu \mathrm{m}$ in the scaffolds are ideal for tissue repair. These parameters of microarchitecture were able to offer a sufficient surface area to volume ratio to enhance neo-vascularization, cell growth and mass transfer [65]. However, porosity and interconnection in the frameworks may be associated with the mechanical strength of the architecture [66]. Consequently, porosity decreases with increase in the number of printed lines in each sheet. Previous reports stated that low mechanical strength of the scaffold may be caused by high porosity $[45,67]$. 
In our study, both PLA and PCL scaffolds displayed sufficient mechanical strength for bone support. Moreover, the data show the swelling ratio of PCL compared with the PLA scaffold. In relation to porosity, the PCL scaffold presented higher surface contact area. This greater superficial contact area may be result of stronger water absorption, inducing a better swelling ratio [39]. Thomas and Windle's model of Case II diffusion verified water uptake is dependent on the pressure caused by swelling of the polymer. Hence, water uptake is strongly influenced by mechanical deformation of the glassy region in response to the swelling of polymer. In the bioassay in vitro, SEM showed that MG-63 cells had more pseudopodia and good cell attachment in the 3D printed PCL scaffolds. This may indicate the 3D printed PCL scaffold has better bone-regeneration ability. This may be related to lactic release and low $\mathrm{pH}$ levels after PLA degradation. As mentioned above, PCL scaffolds may offer more benefits for bone tissue repair. Hence, we used the PCL scaffold for the further in vitro study.

To enhance the biological activity of 3D printed PCL scaffolds, PDA was used to graft TGF- $\beta_{1}$. The induction of osteogenic differentiation mainly depends on the support of growth factors, such as TGF- $\beta_{1}$, which is one of the generally studied growth factors for the enhancement of bone repair in vitro and in vivo. Nevertheless, its actual response remains uncertain. No benefit to bone repair was observed with TGF- $\beta_{1}$ concentration ranging from 0.01 to $0.1 \mathrm{ng} / \mathrm{mL}[68,69]$. When the concentration of TGF- $\beta_{1}$ exceeded $10 \mathrm{ng} / \mathrm{mL}$, it aggregated with the expression of sulfated proteoglycans and aggrecan. However, $100 \mathrm{ng} / \mathrm{mL}$ of TGF- $\beta_{1}$ reduced this osteogenic phenotype [70]. Our study showed a similar result. The ALP activity after MG-63 coculture was more prominent when the level of TGF- $\beta_{1}$ was between 10 and $100 \mathrm{pg} / \mathrm{mL}$ (Figure 8 ). When the $3 \mathrm{D}$ printed scaffold interacted with $20 \mathrm{ng} / \mathrm{mL}$ TGF- $\beta_{1}$, the average releasing level of TGF- $\beta_{1}$ was almost $100 \mathrm{pg} / \mathrm{mL}$ (Figure 7). Hence, we concluded that the best TGF- $\beta_{1}$ concentration for interaction with 3 D printed PCL scaffold was $20 \mathrm{ng} / \mathrm{mL}$ compared with $10 \mathrm{ng} / \mathrm{mL}$. The results showed that PDA could effectively immobilize TGF- $\beta_{1}$ on scaffolds. Moreover, they demonstrated improved cell transformation and adhesion after TGF- $\beta_{1}$ and PDA modification.

A biocompatible material is defined as a material that does not release any toxic matter and supports cell growth that can be evaluated by an MTT assay [71]. The MTT assay in our study showed that PDA and TGF- $\beta_{1}$ products were not only nontoxic agents, but also promoted cell growth. ALP activity, an initial indicator for functionality and differentiation of osteoblast, was measured by the ALP activity assay. The ALP enzyme released by osteo-differentiating cells is important for bone regeneration because it enhances inorganic phosphate generation, which is important for bone formation and mineralization [72,73]. The basic ALP level in the PCL scaffold was higher than that in another reported traditional manufacturing PCL scaffold [74]. This may indicate a better designed framework can offer a better environment for cell growth with the 3D printing technique. The greater presence of ALP activity was noted in cells cultured with the PCL-TGF- $\beta_{1}$ scaffold compared with the pristine PCL and PCL-PDA groups. The ALP study also proved that PDA and TGF- $\beta_{1}$ coating did not affect the activity of osteoblasts. This result also suggests that the PCL scaffolds with TGF- $\beta_{1}$ grafting supported the osteo-differentiation of cultured cells better.

\section{Conclusions}

We designed the 3D printed TGF- $\beta_{1}$-immobilized PDA-grafted PCL scaffold for bone tissue regeneration. Well-interconnected microporous constructions in terms of physical properties were present in the 3D-printed PLA and PCL scaffolds, and they also exhibited satisfactory cell adhesion in vitro. In addition, the PDA coating affected the surface properties of the 3D printed PCL scaffolds and promoted the sustained release and grafting of TGF- $\beta_{1}$. The constant release of TGF- $\beta_{1}$ was helpful for osteogenesis differentiation and cell proliferation. In consequence, the PDA coating method can be applied as an ideal procedure to fix TGF- $\beta_{1}$ onto a 3D-printed scaffold, allowing bone repair in the 3D printed scaffolds with exceptional biocompatibility, enhance cellular growth, and has potential as a 
stem cell delivery system the biological engineering. However, further in vivo studies are necessary for greater understanding of the mechanism of bone regeneration.

Author Contributions: All authors have contributed equally to the work. Methodology, investigation, analysis and study design by Y.-H.L.; polymer resources and investigation by M.-Y.S.; writing, editing and review by C.-H.C.; supervision, validation, and conceptualization by C.-H.Y. and M.-J.L.; funding acquisition by N.-P.F. All authors have read and agreed to the published version of the manuscript.

Funding: This research was funded by [Tainan Municipal An-Nan Hospital, China Medical University] grant number [ANHRF110-04].

Institutional Review Board Statement: Not applicable.

Informed Consent Statement: Not applicable.

Acknowledgments: This work was supported by the Tainan Municipal An-Nan Hospital, China Medical University (ANHRF110-04).

Conflicts of Interest: The authors report no conflict of interest. The funders had no role in the organization of the research, in the decision to publish the research data, in the writing of the article content, or interpretation of results, analysis or data collection.

\section{References}

1. Henkel, J.; Woodruff, M.A.; Epari, D.R.; Steck, R.; Glatt, V.; Dickinson, I.C.; Choong, P.F.; Schuetz, M.A.; Hutmacher, D.W. Bone Regeneration Based on Tissue Engineering Conceptions-A 21st Century Perspective. Bone Res. 2013, 1, 216-248. [CrossRef]

2. McAllister, B.S.; Haghighat, K. Bone Augmentation Techniques. J. Periodontol. 2007, 78, 377-396. [CrossRef] [PubMed]

3. Browaeys, H.; Bouvry, P.; De Bruyn, H. A Literature Review on Biomaterials in Sinus Augmentation Procedures. Clin. Implant Dent. Relat. Res. 2007, 9, 166-177. [CrossRef] [PubMed]

4. Aghaloo, T.L.; Moy, P.K. Which Hard Tissue Augmentation Techniques Are the Most Successful in Furnishing Bony Support for Implant Placement? Int. J. Oral Maxillofac. Implants 2007, 22, 49-70.

5. Moore, W.R.; Graves, S.E.; Bain, G.I. Synthetic Bone Graft Substitutes. ANZ J. Surg. 2001, 71, 354-361. [CrossRef]

6. Navarro, M.; Michiardi, A.; Castaño, O.; Planell, J.A. Biomaterials in Orthopaedics. J. R. Soc. Interface 2008, 5, 1137-1158. [CrossRef] [PubMed]

7. Rezwan, K.; Chen, Q.Z.; Blaker, J.J.; Boccaccini, A.R. Biodegradable and Bioactive Porous Polymer/Inorganic Composite Scaffolds for Bone Tissue Engineering. Biomaterials 2006, 27, 3413-3431. [CrossRef] [PubMed]

8. Khorasani, M.; Ghasemi, A.; Rolfe, B.; Gibson, I. Additive manufacturing a powerful tool for the aerospace industry. Rapid Prototyp. J. 2021. [CrossRef]

9. Travieso-Rodriguez, J.A.; Jerez-Mesa, R.; Llumà, J.; Gomez-Gras, G.; Casadesus, O. Comparative study of the flexural properties of ABS, PLA and a PLA-wood composite manufactured through fused filament fabrication. Rapid Prototyp. J. 2021, $27,81-92$. [CrossRef]

10. Habibovic, P.; Gbureck, U.; Doillon, C.J.; Bassett, D.C.; van Blitterswijk, C.A.; Barralet, J.E. Osteoconduction and Osteoinduction of Low-Temperature 3D Printed Bioceramic Implants. Biomaterials 2008, 29, 944-953. [CrossRef]

11. Luo, Y.; Wu, C.; Lode, A.; Gelinsky, M. Hierarchical Mesoporous Bioactive Glass/Alginate Composite Scaffolds Fabricated by Three-Dimensional Plotting for Bone Tissue Engineering. Biofabrication 2013, 5, 015005. [CrossRef]

12. Yang, C.; Wang, X.; Ma, B.; Zhu, H.; Huan, Z.; Ma, N.; Wu, C.; Chang, J. 3D-Printed Bioactive Ca3SiO5 Bone Cement Scaffolds with Nano Surface Structure for Bone Regeneration. ACS Appl. Mater. Interfaces 2017, 9, 5757-5767. [CrossRef] [PubMed]

13. Montjovent, M.O.; Mathieu, L.; Schmoekel, H.; Mark, S.; Bourban, P.E.; Zambelli, P.Y.; Laurent-Applegate, L.A.; Pioletti, D.P. Repair of Critical Size Defects in the Rat Cranium Using Ceramic-Reinforced PLA Scaffolds Obtained by Supercritical Gas Foaming. J. Biomed. Mater. Res. A 2007, 83, 41-51. [CrossRef] [PubMed]

14. Abdal-Hay, A.; Sheikh, F.A.; Lim, J.K. Air Jet Spinning of Hydroxyapatite/Poly(Lactic Acid) Hybrid Nanocomposite Membrane Mats for Bone Tissue Engineering. Colloids Surf. B Biointerfaces 2013, 102, 635-643. [CrossRef] [PubMed]

15. Kothapalli, C.R.; Shaw, M.T.; Wei, M. Biodegradable HA-PLA 3-D Porous Scaffolds: Effect of Nano-Sized Filler Content on Scaffold Properties. Acta Biomater. 2005, 1, 653-662. [CrossRef]

16. Jeong, S.I.; Ko, E.K.; Yum, J.; Jung, C.H.; Lee, Y.M.; Shin, H. Nanofibrous Poly(Lactic Acid)/Hydroxyapatite Composite Scaffolds for Guided Tissue Regeneration. Macromol. Biosci. 2008, 8, 328-338. [CrossRef]

17. Guvendiren, M.; Molde, J.; Soares, R.M.; Kohn, J. Designing Biomaterials for 3D Printing. ACS Biomater. Sci. Eng. 2016, 2, 1679-1693. [CrossRef] [PubMed]

18. Vidakis, N.; Petousis, M.; Savvakis, K.; Maniadi, A.; Koudoumas, E. A comprehensive investigation of the mechanical behavior and the dielectrics of pure polylactic acid (PLA) and PLA with graphene (GnP) in fused deposition modeling (FDM). Int. J. Plast. Technol. 2019, 23, 195-206. [CrossRef] 
19. Kumar, M.P.; Ponnusamy, S.; Reddy Nallamilli, M.S. The influence of process parameters on the impact resistance of 3D printed PLA specimens under water-absorption and heat-treated conditions. Rapid Prototyp. J. 2021, 27, 1108-1123. [CrossRef]

20. Afonso, J.A.; Alves, J.L.; Caldas, G.; Gouveia, B.P.; Santana, L.; Belinha, J. Influence of 3D printing process parameters on the mechanical properties and mass of PLA parts and predictive models. Rapid Prototyp. J. 2021, 27, 487-495. [CrossRef]

21. Von Windheim, N.; Collinson, D.W.; Lau, T.; Brinson, L.C.; Gall, K. The influence of porosity, crystallinity and interlayer adhesion on the tensile strength of 3D printed polylactic acid (PLA). Rapid Prototyp. J. 2021, 27, 1327-1336. [CrossRef]

22. Athanasiou, K.A.; Niederauer, G.G.; Agrawal, C.M. Sterilization, Toxicity, Biocompatibility and Clinical Applications of Polylactic Acid/Polyglycolic Acid Copolymers. Biomaterials 1996, 17, 93-102. [CrossRef]

23. Mikos, A.G.; Sarakinos, G.; Leite, S.M.; Vacanti, J.P.; Langer, R. Laminated Three-Dimensional Biodegradable Foams for Use in Tissue Engineering. Biomaterials 1993, 14, 323-330. [CrossRef]

24. Brekke, J.H.; Olson, R.A.; Scully, J.R.; Osbon, D.B. Influence of Polylactic Acid Mesh on the Incidence of Localized Osteitis. Oral Surg. Oral Med. Oral Pathol. 1983, 56, 240-245. [CrossRef]

25. Levy, F.E.; Hollinger, J.O.; Szachowicz, E.H. Effect of a Bioresorbable Film on Regeneration of Cranial Bone. Plast. Reconstr. Surg. 1994, 93, 307-311. [CrossRef]

26. Hollinger, J.O. Preliminary Report on the Osteogenic Potential of a Biodegradable Copolymer of Polyactide (PLA) and Polyglycolide (PGA). J. Biomed. Mater. Res. 1983, 17, 71-82. [CrossRef] [PubMed]

27. Mandakhbayar, N.; El-Fiqi, A.; Lee, J.H.; Kim, H.W. Evaluation of Strontium-Doped Nanobioactive Glass Cement for Dentin-Pulp Complex Regeneration Therapy. ACS Biomater. Sci. Eng. 2019, 5, 6117-6126. [CrossRef] [PubMed]

28. Siddiqui, N.; Kishori, B.; Rao, S.; Anjum, M.; Hemanth, V.; Das, S.; Jabbari, E. Electropsun Polycaprolactone Fibres in Bone Tissue Engineering: A Review. Mol. Biotechnol. 2021, 63, 363-388. [CrossRef]

29. Loh, Q.L.; Choong, C. Three-Dimensional Scaffolds for Tissue Engineering Applications: Role of Porosity and Pore Size. Tissue Eng. Part B Rev. 2013, 19, 485-502. [CrossRef] [PubMed]

30. Kumari, A.; Yadav, S.K.; Yadav, S.C. Biodegradable Polymeric Nanoparticles Based Drug Delivery Systems. Colloids Surf. B Biointerfaces 2010, 75, 1-18. [CrossRef]

31. Clover, J.; Gowen, M. Are MG-63 and HOS TE85 human osteosarcoma cell lines representative models of the osteoblastic phenotype? Bone 1994, 15, 585-591. [CrossRef]

32. Christoph, P.; Matthias, S.; Thomas, T.; Andreas, K.; Peter, N.; Wolf, M.; Stefan, M. Characterization of Osteosarcoma Cell Lines MG-63, Saos-2 and U-2 OS in Comparison to Human Osteoblasts. Anticancer Res. 2004, 24, 3743-3748.

33. Chia, H.N.; Wu, B.M. Recent Advances in 3D Printing of Biomaterials. J. Biol. Eng. 2015, 9, 4. [CrossRef]

34. Asti, A.; Gioglio, L. Natural and Synthetic Biodegradable Polymers: Different Scaffolds for Cell Expansion and Tissue Formation. Int. J. Artif. Organs 2014, 37, 187-205. [CrossRef]

35. Nijhuis, A.W.; van den Beucken, J.J.; Boerman, O.C.; Jansen, J.A.; Leeuwenburgh, S.C. 1-Step Versus 2-Step Immobilization of Alkaline Phosphatase and Bone Morphogenetic protein-2 onto Implant Surfaces Using Polydopamine. Tissue Eng. Part C Methods 2013, 19, 610-619. [CrossRef] [PubMed]

36. Cho, H.J.; Perikamana, S.K.; Lee, J.H.; Lee, J.; Lee, K.M.; Shin, C.S.; Shin, H. Effective Immobilization of BMP-2 Mediated by Polydopamine Coating on Biodegradable Nanofibers for Enhanced In Vivo Bone Formation. ACS Appl. Mater. Interfaces 2014, 6 , 11225-11235. [CrossRef] [PubMed]

37. Kang, J.; Tada, S.; Kitajima, T.; Son, T.I.; Aigaki, T.; Ito, Y. Immobilization of Bone Morphogenetic Protein on DOPA- or DopamineTreated Titanium Surfaces to Enhance Osseointegration. BioMed Res. Int. 2013, 2013, 265980. [CrossRef]

38. Tsai, W.B.; Chen, W.T.; Chien, H.W.; Kuo, W.H.; Wang, M.J. Poly(Dopamine) Coating to Biodegradable Polymers for Bone Tissue Engineering. J. Biomater. Appl. 2014, 28, 837-848. [CrossRef]

39. Ko, E.; Yang, K.; Shin, J.; Cho, S.W. Polydopamine-Assisted Osteoinductive Peptide Immobilization of Polymer Scaffolds for Enhanced Bone Regeneration by Human Adipose-Derived Stem Cells. Biomacromolecules 2013, 14, 3202-3213. [CrossRef]

40. Hiyama, A.; Gogate, S.S.; Gajghate, S.; Mochida, J.; Shapiro, I.M.; Risbud, M.V. BMP-2 and TGF-Beta Stimulate Expression of beta1,3-glucuronosyl Transferase 1 (GlcAT-1) in Nucleus Pulposus Cells Through AP1, TonEBP, and Sp1: Role of MAPKs. J. Bone Miner. Res. 2010, 25, 1179-1190. [PubMed]

41. Kawaguchi, H.; Oka, H.; Jingushi, S.; Izumi, T.; Fukunaga, M.; Sato, K.; Matsushita, T.; Nakamura, K. A Local Application of Recombinant Human Fibroblast Growth Factor 2 for Tibial Shaft Fractures: A Randomized, Placebo-Controlled Trial. J. Bone Miner. Res. 2010, 25, 2735-2743. [CrossRef]

42. Wang, Z.; Sun, J.; Li, Y.; Chen, C.; Xu, Y.; Zang, X.; Li, L.; Meng, K. Experimental Study of the Synergistic Effect and Network Regulation Mechanisms of an Applied Combination of BMP-2, VEGF, and TGF-beta1 on Osteogenic Differentiation. J. Cell. Biochem. 2020, 121, 2394-2405. [CrossRef]

43. Li, Z.; Leung, M.; Hopper, R.; Ellenbogen, R.; Zhang, M. Feeder-Free Self-Renewal of Human Embryonic Stem Cells in 3D Porous Natural Polymer Scaffolds. Biomaterials 2010, 31, 404-412. [CrossRef] [PubMed]

44. Wang, C.C.; Yang, K.C.; Lin, K.H.; Liu, H.C.; Lin, F.H. A Highly Organized Three-Dimensional Alginate Scaffold for Cartilage Tissue Engineering Prepared by Microfluidic Technology. Biomaterials 2011, 32, 7118-7126. [CrossRef]

45. Cheng, C.H.; Chen, Y.W.; Kai-Xing Lee, A.; Yao, C.H.; Shie, M.Y. Development of Mussel-Inspired 3D-Printed Poly (Lactic Acid) Scaffold Grafted with Bone Morphogenetic protein-2 for Stimulating Osteogenesis. J. Mater. Sci. Mater. Med. $2019,30,78$. [CrossRef] 
46. Mata, A.; Kim, E.J.; Boehm, C.A.; Fleischman, A.J.; Muschler, G.F.; Roy, S. A Three-Dimensional Scaffold with Precise MicroArchitecture and Surface Micro-Textures. Biomaterials 2009, 30, 4610-4617. [CrossRef] [PubMed]

47. Borden, M.; Attawia, M.; Khan, Y.; Laurencin, C.T. Tissue Engineered Microsphere-Based Matrices for Bone Repair: Design and Evaluation. Biomaterials 2002, 23, 551-559. [CrossRef]

48. Carter, D.R.; Spengler, D.M. Mechanical Properties and Composition of Cortical Bone. Clin. Orthop. Relat. Res. 1978, 135, 192-217. [CrossRef]

49. Gibson, L.J. The Mechanical Behaviour of Cancellous Bone. J. Biomech. 1985, 18, 317-328. [CrossRef]

50. Havaldar, R.; Pilli, S.C.; Putti, B.B. Insights into the Effects of Tensile and Compressive Loadings on Human Femur Bone. Adv. Biomed. Res. 2014, 3, 101. [CrossRef] [PubMed]

51. Mohebbi-Kalhori, D.; Behzadmehr, A.; Doillon, C.J.; Hadjizadeh, A. Computational Modeling of Adherent Cell Growth in a Hollow-Fiber Membrane Bioreactor for Large-Scale 3-D Bone Tissue Engineering. J. Artif. Organs 2012, 15, 250-265. [CrossRef]

52. Li, F.; Wang, S.; Liu, W.; Chen, G. [Progress on Biodegradation of Polylactic Acid-A Review]. Wei Sheng Wu Xue Bao 2008, 48, 262-268.

53. Mackenzie, C.G.; Mackenzie, J.B.; Beck, P. The Effect of pH on Growth, Protein Synthesis, and Lipid-Rich Particles of Cultured Mammalian Cells. J. Biophys. Biochem. Cytol. 1961, 9, 141-156. [CrossRef] [PubMed]

54. Hand, S.; Wang, B.; Chu, K.H. Biodegradation of 1,4-Dioxane: Effects of Enzyme Inducers and Trichloroethylene. Sci. Total Environ. 2015, 520, 154-159. [CrossRef] [PubMed]

55. Malysheva, K.V.; Spasyuk, I.M.; Pavlenko, O.K.; Stoika, R.S.; Gorchynskyi, O.G. Generation of Optimized Preparations of Bone Morphogenetic Proteins for Bone Regeneration. Ukr. Biochem. J. 2016, 88, 87-97. [CrossRef] [PubMed]

56. Zhao, X.; Han, Y.; Li, J.; Cai, B.; Gao, H.; Feng, W.; Li, S.; Liu, J.; Li, D. BMP-2 Immobilized PLGA/Hydroxyapatite Fibrous Scaffold via Polydopamine Stimulates Osteoblast Growth. Mater. Sci. Eng. C Mater. Biol. Appl. 2017, 78, 658-666. [CrossRef] [PubMed]

57. Chien, C.Y.; Tsai, W.B. Poly(Dopamine)-Assisted Immobilization of Arg-Gly-Asp Peptides, Hydroxyapatite, and Bone Morphogenic protein-2 on Titanium to Improve the Osteogenesis of Bone Marrow Stem Cells. ACS Appl. Mater. Interfaces 2013, 5, 6975-6983. [CrossRef] [PubMed]

58. Ritz, U.; Gerke, R.; Götz, H.; Stein, S.; Rommens, P.M. A New Bone Substitute Developed from 3D-Prints of Polylactide (PLA) Loaded with Collagen I: An In Vitro Study. Int. J. Mol. Sci. 2017, 18, 2569. [CrossRef]

59. Bittner, S.M.; Guo, J.L.; Mikos, A.G. Spatiotemporal Control of Growth Factors in Three-Dimensional Printed Scaffolds. Bioprinting 2018, 12, e00032. [CrossRef]

60. Bittner, S.M.; Guo, J.L.; Melchiorri, A.; Mikos, A.G. Three-Dimensional Printing of Multilayered Tissue Engineering Scaffolds. Mater. Today 2018, 21, 861-874. [CrossRef] [PubMed]

61. Guo, J.L.; Diaz-Gomez, L.; Xie, V.Y.; Bittner, S.M.; Jiang, E.Y.; Wang, B.; Mikos, A.G. Three-Dimensional Printing of Click Functionalized, Peptide Patterned Scaffolds for Osteochondral Tissue Engineering. Bioprinting 2021, 22, e00136. [CrossRef] [PubMed]

62. Visser, J.; Melchels, F.P.; Jeon, J.E.; van Bussel, E.M.; Kimpton, L.S.; Byrne, H.M.; Dhert, W.J.; Dalton, P.D.; Hutmacher, D.W.; Malda, J. Reinforcement of Hydrogels Using Three-Dimensionally Printed Microfibres. Nat. Commun. 2015, 6, 6933. [CrossRef] [PubMed]

63. Jakus, A.E.; Rutz, A.L.; Jordan, S.W.; Kannan, A.; Mitchell, S.M.; Yun, C.; Koube, K.D.; Yoo, S.C.; Whiteley, H.E.; Richter, C.P.; et al. Hyperelastic. 'Bone': A Highly Versatile, Growth Factor-Free, Osteoregenerative, Scalable, and Surgically Friendly Biomaterial. Sci. Transl. Med. 2016, 8, 358ra127. [CrossRef] [PubMed]

64. Guo, W.; Chen, M.; Wang, Z.; Tian, Y.; Zheng, J.; Gao, S.; Li, Y.; Zheng, Y.; Li, X.; Huang, J.; et al. 3D-Printed Cell-Free PCL-MECM Scaffold with Biomimetic Micro-Structure and Micro-Environment to Enhance In Situ Meniscus Regeneration. Bioact. Mater. 2021, 6, 3620-3633. [CrossRef] [PubMed]

65. Sarker, B.; Li, W.; Zheng, K.; Detsch, R.; Boccaccini, A.R. Designing Porous Bone Tissue Engineering Scaffolds with Enhanced Mechanical Properties from Composite Hydrogels Composed of Modified Alginate, Gelatin, and Bioactive Glass. ACS Biomater. Sci. Eng. 2016, 2, 2240-2254. [CrossRef]

66. Rustom, L.E.; Boudou, T.; Nemke, B.W.; Lu, Y.; Hoelzle, D.J.; Markel, M.D.; Picart, C.; Wagoner Johnson, A.J. Multiscale Porosity Directs Bone Regeneration in Biphasic Calcium Phosphate Scaffolds. ACS Biomater. Sci. Eng. 2017, 3, 2768-2778. [CrossRef] [PubMed]

67. Link, D.P.; van den Dolder, J.; van den Beucken, J.J.; Wolke, J.G.; Mikos, A.G.; Jansen, J.A. Bone Response and Mechanical Strength of Rabbit Femoral Defects Filled with Injectable CaP Cements Containing TGF-Beta 1 Loaded Gelatin Microparticles. Biomaterials 2008, 29, 675-682. [CrossRef]

68. Lamparelli, E.P.; Lovecchio, J.; Ciardulli, M.C.; Giudice, V.; Dale, T.P.; Selleri, C.; Forsyth, N.; Giordano, E.; Maffulli, N.; Della Porta, G. Chondrogenic Commitment of Human Bone Marrow Mesenchymal Stem Cells in a Perfused Collagen Hydrogel Functionalized with hTGF-beta1-Releasing PLGA Microcarrier. Pharmaceutics 2021, 13, 399. [CrossRef]

69. Yoo, J.U.; Barthel, T.S.; Nishimura, K.; Solchaga, L.; Caplan, A.I.; Goldberg, V.M.; Johnstone, B. The Chondrogenic Potential of Human Bone-Marrow-Derived Mesenchymal Progenitor Cells. J. Bone Jt. Surg. Am. 1998, 80, 1745-1757. [CrossRef]

70. Huang, J.I.; Zuk, P.A.; Jones, N.F.; Zhu, M.; Lorenz, H.P.; Hedrick, M.H.; Benhaim, P. Chondrogenic Potential of Multipotential Cells from Human Adipose Tissue. Plast. Reconstr. Surg. 2004, 113, 585-594. [CrossRef] [PubMed] 
71. Moyers-Montoya, E.D.; Escobedo-González, R.G.; Vargas-Requena, C.L.; Garcia-Casillas, P.E.; Martínez-Pérez, C.A. Epithelial Growth Factor-Anchored on Polycaprolactone/6-Deoxy-6-Amino-Beta-Cyclodextrin Nanofibers: In Vitro and In Vivo Evaluation. Polymers 2021, 13, 1303. [CrossRef] [PubMed]

72. Wang, Z.; Li, M.; Yu, B.; Cao, L.; Yang, Q.; Su, J. Nanocalcium-Deficient Hydroxyapatite-Poly (e-Caprolactone)-Polyethylene Glycol-Poly (e-Caprolactone) Composite Scaffolds. Int. J. Nanomed. 2012, 7, 3123-3131.

73. Mostafavi, A.; Abudula, T.; Russell, C.S.; Mostafavi, E.; Williams, T.J.; Salah, N.; Alshahrie, A.; Harris, S.; Basri, S.M.M.; Mishra, Y.K.; et al. In Situ Printing of Scaffolds for Reconstruction of Bone Defects. Acta Biomater. 2021, 127, 313-326. [CrossRef] [PubMed]

74. Ismail, R.; Pedram, A.; Sha'ban, M.; Wan, K.Z.W.S.; Belinda, P.; Kien, H.C. Polycaprolactone-Based Scaffolds Facilitates Osteogenic Differentiation of Human Adipose-Derived Stem Cells in a Co-Culture System. Polymers 2021, 13, 597. 